\title{
A Great Lesson of Spirituality and Humanism. Pope John Paul II at the Headquarters of UNESCO in Paris (2 June 1980)
}

\begin{abstract}
The speech given by St. Pope John Paul II at the UNESCO headquarters in Paris on June 2, 1980 has a special place among his numerous addresses concerning culture. Referring to the cultural changes which took place in the last three centuries the pope stood up for culture, emphasising that, in an individual dimension, culture represents the constitutive element of life of every man and, correspondingly, in a social dimension, it provides a support for self-determination and for the freedom of nations. Formulating such a message, the pope referred to Polish experiences, in order to highlight the significance and the primacy of the person and to point out the subjective meaning of a nation and the ethical dimension of culture. In the papal message one can also find a call for cultural opposition against contemporary subjectivism and other tendencies heading towards the disinheritance of man and to the shutting of the door of the universal horizon of hope and love, which is based on manifold human experiences from the past.
\end{abstract}

\section{Keywords}

UNESCO, culture, nation, person, ethos, love, hope. 
"Oui! l'avenir de l'homme dépend de la culture. OQui! la paix du monde dépend de la primauté de l'Esprit! Oui! l'avenir pacifique de l'humanité dépend de l'amour!" - Yes! The future of man depends on culture. Yes! The peace of the world depends on the primacy of the Spirit! Yes! The peaceful future of mankind depends on love!" - In these words, both elevated and yet close to every man, Pope John Paul II finished his address at the headquarters of the United Nations Educational, Scientific and Cultural Organization (UNESCO) in Paris on 2 June 1980. ${ }^{1}$ This address cannot be forgotten; it cannot be forgotten, not now nor in the future. The speech given almost forty years ago remains undoubtedly one of the most significant speeches which John Paul II delivered during his entire pontificate. Not only did the speech make a tremendous impression on the international elite listening to it, but it also, as it may be presumed, had a real effect on the events of the 1980s, even if this cannot be proven empirically by indicating its direct consequences. Undoubtedly, it served as a stimulus for the actions which were aimed to rescue man, often from himself. The numerous and constant references to the speech of Pope John Paul II at UNESCO's headquarters in many different parts of the world, and the bringing of its message to fruition could be considered as evidence of its effect. Those who heard the address, those who remember it and those who have been referring to it, all know how great a lesson of spirituality and humanism it was. The Pope addressed his message to the whole humankind, beholding its convoluted spiritual condition with concern. He addresed humankind which, because of the tormenting anxieties and conflicts, was standing on the verge of a global conflict that could have eventuated in an ultimate disaster. Pope John Paul II, through his teachings stemming both from the Gospel and from the Polish spiritual and cultural experience, and through the word inspired by a prophetic spirit, in the light of the Word of God, courageously interpreted the events and phenomena taking place at that time, and simultaneously, provided the humankind with a new perspective of hope built on the primacy of the Spirit and ethical culture, which finds its highest expression and crowning in love. Unsurprisingly, this incredibly demanding message was interrupted by long applauses twenty-nine times. Although during his entire pontificate John Paul II's speeches were always enthusiastically received by his audience all around the world, this particular

${ }^{1}$ Giovanni Paolo II, L'allocuzione all'Organizzazione delle Nazioni Unite per l'Educazione, la Scienza e la Cultura (2 giugno 1980), 23, in: Insegnamenti di Giovanni Paolo II, vol. III, 1, Città del Vaticano 1980, p. 1655 (the whole address pp. 1636-1655). 
address was remarkable in terms of the approval with which it met among the debaters.

Jean-Bernard Raimond (1926-2016), a former French Foreign Minister and the ambassador to the Holy See, in a significant book John Paul II. A Pope at the heart of history, which unfortunately has not met with much recognition in Poland due to a completely different political point of view on the pope from Cracow from the one to which Polish people are used to, describes the event which took place in Paris as follows: "Sitting in this great conference hall of UNESCO, I was scrutinizing the guests present. It was a demanding audience, difficult indeed, consisting of countless diplomats, journalists, eminent scholars, so much Parisian in their everyday life, yet coming from all possible corners of the world, epitomising scepticism, mistrust and a certain dose of disappointment. However, as soon as this deep and warm voice could be heard a complete silence fell on the room and lasted incessantly until the end of the long speech. With the emphasis on truth, with the profundity of thought, with the pursuit of what is the most essential, or maybe with his personal and spontaneous approach, the successor of Saint Peter subdued this whole intellectual elite, who suddenly instead of an abstract and sublime address could hear a description, delivered in an impeccable French, of a world in which man lost his dignity. This pope, this representative of the Church, in his prime (he was sixty then), not struck by the assassin yet, was touching the core issues in his free and disinterested thought, in one of the greatest political speeches after the Second World War."2

Although a long time has passed since it was written, this testimony is still worth noting, especially when the origin and the significance of the author in the political life of France is taken into consideration. In the liberal context of the time in which Raimond was politically active, the message of the Pope was not only supportive for his conservatism but it also strengthened his objective and universalistic attitude, which he always looked for and which he tried to promote in culture and politics. Raimond was perfectly aware that all the actions, especially political and cultural have to surpass the temporal pragmatism and temporal expectations of this or that political party. In order to serve as a foundation for the common welfare and to bring the beneficial effect for society, all the actions have to be supported and justified universally, since only

2 J.-B. Raimond, Jean-Paul II. Un Pape au coeur de l'Histoire, Paris 1999 (excerpt translated into English by P. Piasecki from Polish translation: Jan Paweł II. Papież w samym sercu Historii. Apostoł prawdy i wolności jako dyplomata i polityk, transl. T. Olszewski, Gniezno 2000, p. 26). 
then they serve to what is humane and common. This is the aspect which Raimond emphasises in his interpretation of the pontificate of John Paul II, which is included in the book mentioned above. This is worth appreciating also today when the spiritual condition of nations seems to be much more difficult than it was at the turn of 1970 and ' 80 os.

\section{The times of change}

To realise the importance and the prophetic significance of the address given by Pope John Paul II at the UNESCO's headquarters in 1980 one has to bear in mind a profound cultural and ideological breakthrough which took place in Europe at the threshold of the modern era and to which the pope frequently referred in his statements. This breakthrough is constituted by a change in thinking, which was started by Descartes (1596-1650) with his best known philosophical statement "Ego cogito, ergo sum - I think, therefore I am". It was not, to be sure, directly intended by Descartes but the "new" philosophical principle opened the road leading to the advent of a new way of thinking which today is, indeed, known as "modern". Its key characteristic feature is immanentism. The unilateral support for immanentism leads in consequence to the rejection of what is transcendental and what expresses most visibly in renouncing metaphysics. Then, it comes to the challenging of "the foundation",that is, of the very basics of the understanding of human and the world and the principles on which the existence of man and his actions in this world should be grounded. ${ }^{3}$ This problem was most extensively presented in John Paul II's encyclical letter Fides et ratio (14 September 1998), which regrettably has not been sufficiently appreciated yet, with substantial references to the great Christian tradition and especially to St. Thomas Aquinas. ${ }^{4}$

This issue, which is essential for modern thought and culture, was thoroughly considered by John Paul II. He was preoccupied by this issue during his entire intellectual journey, especially when, as a philosopher, he ran classes at the Catholic University of Lublin, even though he did not gain any particular understanding

${ }^{3}$ Cf. G. Kalinowski, L'impossible métaphysique, Paris 1981.

${ }^{4}$ Cf. J. Cottier, Tommaso d'Aquino, teologo e filosofo, alla luce di «Fides et ratio», in: Fede e ragione. Opposizione, composizione?, a cura di M. Mantovani, S. Thuruthiyil, M. Toso, Roma 1999, pp. 187-194. 
of his ideas among the representatives of that scientific milieu. Giving his lectures Wojtyła-philosopher discovered, that the primary problem of contemporary culture is man as a person. ${ }^{5}$ Synthetically speaking, there is a metaphysical problem here, in its critical moment, because the notion of a person is the most basic anthropological notion which also places itself exactly in a metaphysical context, and only in this context can it be understood and applied. The ethical dilemma appears only secondarily, and it results from an inadequate metaphysics or philosophical anthropology. The crisis of anthropology lies at the basis of the crisis of ethics, which John Paul II realized already during the Second Vatican Council. ${ }^{6}$ That is why his entire pontificate can be analysed from the anthropocentric point of view when this entire effort is recognised as an attempt to rebuild the adequate understanding of a person, without which there is no chance for the authentic preaching of Christian proclamation.

Numerous critics of Pope John Paul II who depreciate his message using the emphasis on man as their weapon are wrong, even if they claim to act in defence of the Christian proclamation. Is it not true that the notion of person constitutes the center of the Christian message?

Can the Christian message be accepted without the adequate understanding of the 'person'? In my opinion, at this point, it is enough to refer to the following historic argument: the Early Church coming out into the world to preach the redemptive incarnation of the Son of God started its actions from the transformation of the ancient vision of man, since only the adequate, new vision of man makes it possible to grasp the essence and significance of the redemptive proclamation of Jesus Christ and open to its appreciation and acceptance. Teaching about Christ requires the appropriate anthropological "climate". Ancient thinkers already noticed that Christ, first of all, creates a new man. Hence, Marius Victorinus could write: "Cum cognos scimus Christum, viri efficimur - When we meet Christ, we become humans."

Something similar takes place in our times - the new vision of man in Jesus Christ has to be the central point of spiritual and cultural work and that is why the question of man needs a lot of attention. In this context "man is the road

${ }^{5}$ About the significance of K. Wojtyła's anthropology in contemporary debate, conf. Autor de „Personne et acte” de Karol cardinal Wojtyla. Articles et conférences sur une rencontre du thomisme avec la phénoménologie, ed. G. Kalinowski, Aix-en-Provence 1987.

${ }^{6}$ Cf. H. de Lubac, Memoire sur l'occasion de mes écrits, Namur 19922, p. 176.

7 Gaius Marius Victorinus, In Epistulam Pauli ad Ephesios: PL 8, 1276B. 
of the Church" as John Paul II wrote at the beginning of his pontificate in the encyclical letter Redemptor hominis (4 March 1979). He frequently referred to this statement in his later teachings. ${ }^{8}$

What does the Cartesian reversal practically mean and why is it so problematic? Simply speaking, as a result of this breakthrough in thinking God became a "question" which human thought struggles to fathom. Human thought defines the initial "coordinates" of this question and concurrently determines its shape, its manifestation and, as a result, the conclusions derived from this question. In close relation with this affirmation, at the starting point, man demands to make decisions autonomously about what is true or false and what is good or bad. On the other hand, at the final point man wants to make decisions in a way completely devoid of reference to God and the following imperatives. As a result, he becomes the master and the creator of himself. Perhaps, there is nothing extraordinary in these phrases, since the Church Fathers already emphasised that man through his deeds is "the father of himself" and similarly scholastic theology by means of its characteristic language describes man as "causa sui". The actual difference between these perspectives consists in the fact that the traditional approaches consider God as the cause and goal of everything; the permanent, firm and invariable benchmark for anthropological research, even though they are undoubtedly strong in anthropological sense and constitute a significant example of searching for the understanding of man. On the other hand, in the new, or rather, modern perspectives God is challenged "in the name of man" and therefore man occupies indivisibly God's place and considers himself to be the only ruler over himself and the world. Eventually, it leads to idolatry and defiance against God. ${ }^{9}$

Bearing in mind this fundamental reversal in thinking, in Paris, where it primarily took place, Pope John Paul II drew the attention of the listeners to a completely new direction, namely, that in human life, God, tradition grounded on religion, memory and culture have to come first. The Pope's justification is based upon the interpretation of the role of culture in the life of man and nation. That is why culture in the Pope's message is, first of all, connected with

${ }^{8}$ Cf. John Paul II, Enc. Centesimus annus (May 1, 1991), n. 53-62.

9 Cf. J. Królikowski, „Stała pokusa wiary”. Współczesne bałwochwalstwo i jego geneza, „Studia Teologii Dogmatycznej” 3 (2017), p. 89-105. 
memory. ${ }^{10}$ Man belongs to his family, to his nation and to the Church along with their history and experiences which he inherits and which, in a considerable or even in a decisive way, most directly shape his feeling, thinking, experiencing of the events and making personal decisions, which in the new time define himself and his relations. Memory strengthens and consolidates identity which is then prolonged and lives within the nation which is "the great community of men who are united by various ties, but above all, precisely by culture. The Nation exists «through» culture and «for» culture, and it is therefore the great educator of man in order that they may «be more» in the community. It is this community which possesses a history that goes beyond the history of the individual and the family" (n. 14).

According to John Paul II's teachings, man is a creature primarily rooted in what is not his creation, but in what comes from other people, both those who lived long ago and those who are his contemporaries. His existence, his awareness, his customs and the journey he sets out on are mostly dependant on the contribution of others. The acceptance of this fact bears a great existential meaning because, to some extent, at the starting point it includes the call for respect for all that man encounters on his way and what is a gift for him. It also has a great religious significance, one could even say Christian significance, since Christian faith, in its very core, is based upon God's free gift which is revelation, redemption, grace and finally faith itself. Being indebted to others in a cultural sense brings about an important evangelical, apologetical and hermeneutical message, because it opens man to essential Christian experiences and to some extent it constitutes an initial introduction to their celebration (praeparatio evangelica). The scholastic principle, summarizing Christian awareness to some degree, stated that grace (that is, generally all that is Christian) involves nature ${ }^{11}$; today this principle should be completed with the comment that grace involves nature and culture. Such an extension is necessary as far as the teachings of John Paul II are concerned, who frequently pointed out the need to shape culture in the first place, so that the Gospel could be successfully preached on its foundation.

${ }^{10}$ Pope John Paul II derives such an understanding of culture mainly from the eastern religious and philosophical tradition where the notion of culture plays a key role. It is of course possible to discern here the influence of Saint Augustine who regarded memory as a key notion, too, however, it seems that for John Paul II his thought is much less important in this context.

11 Thomas Aquinas, Summa theologiae I q. 1 a. 8 ad 2. 
Therefore, man "owes his existence - verdankte Existenz", as Swiss theologian Hans Urs von Balthasar aptly noticed. ${ }^{12}$ This statement stands in stark contrast to the outlooks which are predominant today and to the propagandist visions of the world which at all costs want to liberate man from all dependencies and connections which he has with the legacy of his ancestors and with the spiritual wealth of the contemporaries, namely with the "goodness" which is beyond man, but without which he is not capable of being himself as a man, and without which he cannot realize his most internal needs and pursuits. That is why, sooner or later, everyone has to return to this inherited wealth, derive from it, confirm its existential necessity so as not to end in the state of spiritual sorrow which is the centre of all crises. Certainly, it requires realism, a sense of criticism and intellectual courage, but to put it straight, it is spiritually rewarding ${ }^{13}$. There is a lot of evidence showing how modern philosophy distinctively elucidates this fact. Since we refer to French experiences, it is possible to mention, at this point, the French philosopher, Jean-Luc Marion, whose ideas are closely related to the categories of gift and the idea of being indebted, which appear to be the most positive aspects of human experience and which allows man to be $\operatorname{man}^{14}$. His anthropology is an attempt to rebuild the vision of man who is rooted in an open humanistic experience which perceives man in the perspective of his manifold references to his surroundings and drawing from its spiritual resources.

It is worth noting that on 11 March 1882, so nearly a hundred years before Pope John Paul II's visit in Paris, at Sorbonne University Joseph-Ernst Renan (1823-1892) gave a famous speech entitled with the question: What is a Nation? $\mathrm{He}$ answered to this question according to the French, or even "republican" conception, that a nation is "the desire clearly expressed to continue living together"15. In his lecture Renan refers mostly to the principles of the French Revolution, trying to show their currency and effectiveness, especially in the perspective of common life and its further building which is worth to sacrifice for. Nevertheless, he also emphasised the significance of those principles for man as a conscious individual.

${ }^{12}$ In der Fülle des Glaubens. Hans Urs von Balthasar-Lesebuch, hrsg. M. Kehl, W. Löser, Basel - Freiburg - Wien 1980, p. 67.

13 Cf. John Paul II, Enc. Fides et ratio, 74.

14 Cf. J.-L. Marion, Étant donné. Essai d’une phénomenologie de la donation, Paris 19982.

15 E. Renan, Qu'est-ce qu’une nation?, Paris 1882, p. 27: "Le désir clairment exprimé de continuer la vie commune". 
In his address in the historical centre of the French Revolution, Pope John Paul II drew the attention to a different direction, namely a more objective, universal, yet, undoubtedly, strongly anthropological one. He concentrated on the issue of culture and the particular one - the Polish culture, in which he was personally an active participant and experienced creator. Referring to tragic Polish historical experiences, especially to the times of the Partitions of Poland and the enslavement of the nation in the $19^{\text {th }}$ century the Pope emphasised that Polish nation, in spite of the partitions, recurrent persecutions, manifold political, economic and cultural pressures manged to keep its national identity and sovereignty "not by relying on the resources of physical power, but solely by relying on its culture" (n. 14). ${ }^{16}$

Man and nation are rooted both in culture and in memory which is a storage of culture. They can find will to survive in all circumstances. In the face of dangers which would threaten their survival they become a strong support for the experienced values and established relations. The cultural memory does not allow anyone to resign from the active participation in culture of any time, but on the contrary, it constitutes the background for this participation and a specific range of resources which serve for the transferring of proven values and make it possible to carry out the actualization of those values according to the spiritual condition of the new times and to the arising challenges. Once again, we can refer to the historic experiences which clearly prove that the diminishing of culture and resignation from its leading ethical and social value resulted in the collapse of even the greatest of civilisations. ${ }^{17}$

\section{Cultural defiance}

It is worth remembering, that in the face of the "uniformization" of the human community which is propagated by the media, and in the face of the pressures from economic powers which try to impose universally applicable action schemes and codes of conduct which are clearly doubtful in terms of ethics, John Paul II, both in Paris and later in his teachings during his pontificate, stressed the need for the cultural opposition against those theories which, under cover of so-called globalisation, are designed simply to take control over man. In these

${ }^{16}$ Cf. R. Buttiglione, Etyka wobec historii, Lublin 1994.

17 Cf. F. Koneczny, Obronić cywilizację łacińską!, Lublin 1992. 
times of the utilitarian subjugation of people and entire nations to contrived and arbitrarily enforced regulations, Pope John Paul II reminded the listeners gathered at UNESCO's headquarters, about the obligation to respect the sovereignty of nations and peoples, which he repeated later many times and in many different places all over the world during his apostolic visits. He spoke: "This sovereignty [...] draws its origin from the specific culture of the Nation and society, from the primacy of the family in the work of education, and finally from the personal dignity of every man" (n. 16). On the basis of his experiences stemming from the national tradition and on the grounds of his philosophical reflections Pope John Paul II strongly emphasised that the identity of national communities manifesting itself in culture, concurrently in the very culture, finds not only its freedom but also the way of development, formation and stability.

Pope John Paul II connected the speech about the sovereignty of nations and peoples with the appeal to make the effort to work out the renewed system of the "the law of the Nation" so that it is suitable for the new times and new cultural standards. Certainly, in this appeal there is also a reference to the Polish historic experiences in which a fully-developed concept of the law of the Nation served to defend Polish sovereignty, but also contributed to the expression of respect towards neighbouring nations and peoples, and to the establishing of relations both internal and external on the foundation of Christian love. John Paul II returned to this significant question in his message proclaimed during his second visit to the headquarters of the United Nations in New York on 5 October 1995, when he once again reminded about the need for the preparation of a new charter of the law of the Nation ${ }^{18}$. Regrettably, this proposal has not met with favourable reception yet, whereas it could bring about the intensification of the activities for peace or for the appropriate perspective on the so- called immigration crisis in today's world.

In the context of the current philosophical and religious disputes, it is worth notng, that John Paul II's appreciation to culture, or even regarding it as superior to some extent is not identical with its absolutisation. On the contrary, it calls for a critical reflection over culture, in order to perform the necessary purification of it and to demonstrate the possibilities of better application of culture for the service of man. Nature constitutes a common sphere for all people and

${ }^{18}$ Cf. Giovanni Paolo II, Il messaggio consegnato nella Sede dell'Organizzazione delle Nazioni Unite, per la celebrazione del 50o di fondazione (New York, 2 giugno 1980), in: Insegnamenti di Giovanni Paolo II, vol. XVIII, 2, Città del Vaticano 1998, p. 730-744. 
for all types of their activity. It is also a criterion for the interpretation of reality and especially for making ethical decisions. That is why nature is superior to culture. ${ }^{19}$ In my opinion, although Pope John Paul II never expressed it in terms of a principle, he proved many times in his lectures, that the fundamental problem of culture today is the question of "nature". It is popular today to speak about ethical crisis or anthropological crisis but it is unfashionable to admit clearly that the most essential is the problem of the concept of nature. Natural sciences and their predominance in contemporary culture are mostly responsible for this situation, since they narrow down nature to matter and biology without any reasonable justification. In the case of nature we should speak about something completely different, as Cardinal Karol Wojtyła argued in his major work The Acting Person: "Nature reveals the dynamism of the subject, that is, it reveals that activeness which is wholly and entirely contained in the subject's dynamic readiness; as if this activeness was from the start an attribute of the subject and was entirely prepared in its subjective dynamic structure."20

Accepting the one nature, common for everyone, which would provide the same guidelines for everyone is an indispensable source of objectivism and universalism in terms of both philosophy and morality. Without nature, understood of course dynamically and subjectively, and not materialistically or in terms of matter, there is no chance for ethics, coherent legislature, culture, not even for simple interpersonal understanding. Without the acceptation of one nature it is impossible to propose universal and obligatory principles of thinking, or to seek for political and social agreement.

Culture embedded in nature, but in a way that it goes rationally beyond the limitations of nature and improves it, is understood by Pope John Paul II as something more, namely as a space of hope which makes man and nations open for the future. Man "expresses himself and objectivizes himself in culture and through culture, is unique, complete and indivisible" (n. 8). He "is the only ontic subject of culture, is also its only object and its term (n. 7). Therefore, the road of man's realisation and the way to face the appearing challenges is the rejection of the material element in favour of the idealistic spiritual forces. Moreover, culture should make a creative and transforming contribution into man's being,

19 Evident manifestation of the misinterpretation of the ideas of nature and culture in today's world is gender ideology. Cf. J. Królikowski, Natura czy kultura, czyli o co toczy się walka $w$ dyskusji o gender?, Tarnów 2014.

${ }^{20}$ K. Wojtyła, Osoba i czyn oraz inne studia antropologiczne, Lublin 1994, p. 127. 
before it broadens the extent of his having, and using of what he has. "Culture is that through which man as man, becomes more man, «is» more, has more access to «being». The fundamental distinction between what man is and what he has, between being and having, has its foundation there too" (n. 7). Thus, it can be said, that thanks to culture man can become man more fully and learn not only how to be «with others», but also «for others» (n. 11).

The message of Pope John Paul II contains the conviction, which draws its inspiration from the Aristotelian Nicomachean Ethics and to which St. Thomas Aquinas refers in his philosophy, that "those who cannot find happiness in spiritual enjoyments, turn to corporeal pleasures." ${ }^{21}$ The lack of spiritual development the integral part of which is culture, as well as the lack of beauty and genuine goodness or the lack of admiration for holiness, they all make it impossible to recognise the value of living in community with others. Instead they promote carnal or material pleasures which would have their source in the unrestricted exploitation of objects and even other people. Crucial decisions and actions which will affect future and its shape always depend on man's perspective on what is spiritual, as well as on man's declaration in favour of the spiritual which eventually means that we express ourselves in favour of the virtues which are crowned with love: "forma omnium virtutum."22

The primacy of nature, and ultimately the primacy of metaphysics, describing objectively and universally who man is instructs us to search for the understanding of man in the direction of "to be", bestowing this aspect of human self-understanding with unquestionable priority. It is not only about the philosophical expression in favour of the primacy of being, but also about grasping of what may constitute certain and universal criterion of human thinking, making decisions, searching for living perspectives and coping with everyday duties. "To be" is what describes the above in terms of expressing one's thoughts but also enduring when life becomes a drudgery, when it worries, when it is destroyed as a result of manifold factors and pressures, when we struggle with our existence with its everyday needs, obligations and restrictions. "The primacy of «to be» over «to have»" which has the support of modern philosophy ${ }^{23}$, which was acknowledged by the Second Vatican Council in the Constitution Gaudium

${ }^{21}$ Thomas Aquinas, Summa theologiae II-II q. 35 a. 4 ad 2 (quotes Nicomachean Ethics $10,5)$.

22 Thomas Aquinas, Summa theologiae I-II q. 62 a. 4.

${ }^{23}$ Cf. G. Marcel, Etre et avoir, Paris 1935. 
et spes (n. 35) and by the succeeding popes - the authentic interpreters ${ }^{24}$, and which is naturally chosen by common sense, can and should become the criterion of human conduct. This primacy should become the benchmark for the interpretation of what constitutes actus humanus, that is human action. That is how man authentically affirms himself, but also transcends himself, since this is his destiny and internal need, which Cardinal Wojtyła thoroughly explained in his treatise The Acting Person.

In the light of the anthropology of gift and reciprocity it is clear that, in the teachings of John Paul II, there is a wide perspective for the acceptance and confirmation of the primacy of the family in general, and in the act of educating man for the real humanity in particular. The question of family is repeated like a refrain in the Pope's address to UNESCO, rightly manifesting itself as the centre of today's cultural problem (n. 13). Family plays an irreplaceable and fundamental role in social and cultural life not only because it brings the next generations into the world securing the future of humanity and the Church. Family constitutes the environment where the identity of human being as a person is celebrated, as a man or a woman. In this environment man is introduced into the world of relations and becomes a successor of the tradition of the preceding generations, and learns to respect their legacy. Last but not least, it is in the family that human conscience is shaped in the largest extent and the adoption of common morals take places, as was already accurately noted by Plato.

\section{The primacy of a person}

The speech of Pope John Paul II to UNESCO is a hymn in honour of a human being, its dignity and various creative abilities, not only in the spiritual sense but also in the field of science, technology, work and the cultural effort wich is underakten, evenlthough from the Christian point of view all those spheres have a distinct spiritual dimension. Taking this into consideration, the Pope's speech, from the very beginning, became a message of hope and performed a trustful opening for the future. In this perspective man appears to be blessed with special and autonomous values; he appears as a dynamic subject, a decision making being, a witness of transcendence and a creative spirit. Thanks to that,

${ }^{24}$ Cf. Paul VI, Enc. Populorum progressio (26 March 1967), 14; John Paal II, Enc. Redemptor hominis, 16. 
man deserves affirmation for his own reason, and that is why it is necessary to always look first to the "spiritual dimension of human existence" (n. 4). Bearing this in mind, Pope John Paul II reminded about the existing and constantly appearing manifold threats and abuses of human capabilities, especially in the field of science, and referred to the representatives of cultural and scientific circles with a hopeful moral appeal: [...] consciences must be mobilized! The efforts of human consciences must be increased in proportion to the tension between good and evil to which men at the end of the twentieth century are subjected. We must convince ourselves of the priority of ethics over technology, of the primacy of the person over things, of the superiority of spirit over matter. The cause of man will be served if science forms an alliance with conscience. The man of science will really help humanity if he keeps «the sense of man's transcendence over the world and of God's over man»". He also added, that: "All together you are an enormous power: the power of intelligences and consciences! Show yourselves to be more powerful than the most powerful in our modern world! Make up your mind to give proof of the most noble solidarity with mankind: founded on the dignity of the human person" (n. 22). This programme is not a utopia if it is based upon the foundation of primacy and the essential meaning of moral culture which is the first and fundamental dimension of culture" (n. 12).

The essential expression of the human spirit is the moral conscience which judges according to God's justice and according to absolute, universal and unchangeable principles. It looks for the greatest possible good, simultaneously denouncing evil, its triviality and by the same token, its most destructive force. The more evil is trivialized, the more space is given to its detrimental influence on man, his relations and his community life. Conscience cannot be deadened, eliminated or subjugated to any of human instances, since it is the bastion of truth about goodness, and correspondingly, it is the bastion of humanity and society. It is worth remembering, especially today, when conscience becomes subjugated in a totalitarian way to the established law in so called liberal democracies. Democracy, which stems from the will to defend conscience, becomes today - which is an indisputable paradox - the enemy of conscience and its autonomy. 


\section{4. "A son of humanity"}

When we reread the address of John Paul II given in Paris in 1980, we cannot overlook both the courage and the strength of argumentation with which he formulated the presented cultural programme, and the prophetic dimension of the speech. This voice certainly had its inspiration in the Pope's personal experiences but also in his firm conviction, that the Church has a leading role in the shaping of culture and in its moral formation. John Paul II declared, that the presence of the Holy See at UNESCO and his address in front of the assembly have their justification in: "[...] the organic and constitutive link which exists between religion in general and Christianity in particular, on the one hand, and culture, on the other hand" (n. 9). However, there is one more justification of this presence in the Pope's speech. He spoke, of course. as Bishop of Rome (Evêque de Rome) but, interestingly, before he referred to his function he simply said, that he speaks as "a son of humanity - fils de l'humanite" (n. 22). Perhaps, that was the greatest ennoblement of human experience in the context of the perspective on the world and its issues which was ever formulated in the Church. The Pope does not only speak as equal among equals but he also derives from his own personal experience just to share it with others. It is experience permeated with faith and its defence, which led him through all his life, but it is also human experience and a universally applicable one. Perhaps, this is why his words touched deeply, not only the listeners but also everyone who gave a thought to the Pope's lecture and to the message sent to the world. Perhaps, this very address saved the world from the nuclear conflict which the Pope mentioned in his speech and about which he wrote in his testament.

Today, almost forty years after the visit of Pope John Paul II at UNESCO's headquarters, the mentioned address still inspires with courage and hope. Aristotle suggestively noticed, that "Genus humanus arte et ratione vivit. - Mankind lives thanks to culture and reason"; the same was firmly repeated by St. Thomas Aquinas ${ }^{25}$ and strongly reminded by John Paul II in Paris, in the face of a difficult moment in the history of humankind (n. 17). Therefore, if man becomes himself through truth, and if he becomes more himself through the increasingly perfect "knowledge of truth", that is, by changing truth into ethos, and if he becomes "cultural phenomenon", then he truly follows the Son of Man confirming, that he is "a son of humanity" who is destined to become a son of God.

25 Thomas Aquinas, Expositio libri Posteriorum Analiticorum, lib. I, lect. 1, 1. 


\section{Bibliography}

Autor de „Personne et acte” de Karol cardinal Wojtyla. Articles et conférences sur une rencontre du thomisme avec la phénoménologie, ed. G. Kalinowski, Aix-en-Provence 1987.

Buttiglione R., Etyka wobec historii, Lublin 1994.

Cottier J., Tommaso d'Aquino, teologo e filosofo, alla luce di «Fides et ratio», in: Fede e ragione. Opposizione, composizione?, a cura di M. Mantovani, S. Thuruthiyil, M. Toso, Roma 1999, pp. 187-194.

Giovanni Paolo II, L'allocuzione all'Organizzazione delle Nazioni Unite per l'Educazione, la Scienza e la Cultura (2 giugno 1980), in: Insegnamenti di Giovanni Paolo II, vol. III, 1, Città del Vaticano 1980, pp. 1636-1655.

Giovanni Paolo II, Il messaggio consegnato nella Sede dell'Organizzazione delle Nazioni Unite, per la celebrazione del 50o di fondazione (New York, 2 giugno 1980), in: Insegnamenti di Giovanni Paolo II, vol. XVIII, 2, Città del Vaticano 1998, p. 730-744.

In der Fülle des Glaubens. Hans Urs von Balthasar-Lesebuch, hrsg. M. Kehl, W. Löser, Basel - Freiburg - Wien 1980.

John Paul II, Enc. Centesimus annus (May 1, 1991).

Koneczny F., Obronić cywilizację łacińską!, Lublin 1992.

Królikowski J., Natura czy kultura, czyli o co toczy się walka w dyskusji o gender?, Tarnów 2014.

Królikowski J., „Stała pokusa wiary”. Współczesne bałwochwalstwo i jego geneza, „Studia Teologii Dogmatycznej" 3 (2017), p. 89-105.

Marcel G., Etre et avoir, Paris 1935.

Marion J.-L., Étant donné. Essai d’une phénomenologie de la donation, Paris 19982.

Paul VI, Enc. Populorum progressio (26 March 1967).

Raimond J.-B., Jean-Paaul II. Un Pape au coeur de l'Histoire, Paris 1999 (Polish translation: Jan Paweł II. Papież w samym sercu Historii. Apostoł prawdy i wolności jako dyplomata i polityk, transl. T. Olszewski, Gniezno 2000.

Kalinowski G., L'impossible métaphysique, Paris 1981.

Lubac H. de, Memoire sur l'occasion de mes écrits, Namur 19922.

Renan E., Qu'est-ce qu'une nation?, Paris 1882.

Thomas Aquinas, Summa theologiae.

Thomas Aquinas, Expositio libri Posteriorum Analiticorum.

Vicotorinus, Gaius Marius, In Epistulam Pauli ad Ephesios: PL 8.

Wojtyła K., Osoba i czyn oraz inne studia antropologiczne, Lublin 1994. 